\title{
KAJIAN MENTAL IMAGE MAHASISWA ARSITEKTUR TERHADAP ARSITEKTUR DENGAN METODE PENDEKATAN SEMIOTIK
}

\author{
Rina Saraswaty, Aulia Muflih Nasution ${ }^{1}$ \\ ${ }^{1}$ Dosen Program Studi Arsitektur Fakultas Teknik, Universitas Medan Area \\ (rinasaraswaty@yahoo.co.id)
}

\begin{abstract}
ABSTRAK
Penelitian ini bertujuan untuk mengetahui seberapa jauh pemahaman seseorang tentang arsitektur dengan membaca tanda yang terdapat pada suatu objek arsitektur. Sebagai mahasiswa baru jurusan teknik Arsitektur tahun 2015, dapat disejajarkan dengan masyarakat awam yang belum mendapatkan pendidikan arsitektur sehingga pemahaman tentang arsitektur masih beragam. Dengan demikian akan diperoleh indikator materi pembelajaran yang dapat disesuaikan dengan tingkat pemahaman mahasiswa sehingga akan diperoleh faktor-faktor perangsang ketekunan menjalani pendidikan arsitektur. Perbedaan tingkat pemahaman terhadap arsitektur tersebut dipengaruhi oleh latar belakang sosial, ekonomi dan lingkungan atau budaya yang berbeda. Karya arsitektur yang dijadikan obyek pengamatan pada penelitian ini adalah rumah tinggal karena rumah tinggal merupakan obyek arsitektur yang umum dan paling mudah untuk dikenal dan dibaca. Sebab informasi yang disampaikan mengenai apakah "dia" sebenarnya dan apa yang "dia" lakukan dapat membuat pengamat mengetahui makna sebenarnya. Untuk membaca tanda sebagai pemahaman arsitektur dapat dilakukan melalui metode pendekatan, yaitu melalui metode semiotika. Dimana melalui metode pendekatan ini si pengamat dapat melakukan cara melihat tanda baik untuk disusun maupun dibaca sebagai suatu bahasa. Luaran dari penelitian ini berupa artikel ilmiah yang dipublikasikan di Jurnal Lokal ISSN. Hasil penelitian ini diharapkan menjadi pedoman pendidikan arsitektur khususnya di perguruan tinggi didalam membuat kebijakan penyusunan kurikulum dan silabus materi perkuliahan agar diperoleh suatu kebijakan kurikulum yang tepat dan berbobot bagi sistem pendidikan dasar arsitektur serta pengayaan materi mata kuliah Pengantar Arsitektur. Dengan demikian, mahasiswa yang menjalani pendidikan arsitektur dapat memahami arsitektur dengan maksimal dan mudah untuk mengaplikasikan di lapangan.
\end{abstract}

Kata Kunci : arsitektur, kurikulum, mahasiswa arsitektur, mental image, rumah tinggal, ,semiotika

\section{ABSTRACT}

This study aims to find out how far one's understanding of architecture by reading the signs contained in an architectural object. As a freshman majoring in engineering Architecture 2015, can be equated with ordinary people who have not received an architectural education so that his understanding of architecture is still diverse. Thus will be obtained indicator of learning materials that can be adjusted to the level of understanding of students that will be obtained factors stimulating perseverance undergo architectural education. Differences in levels of understanding of the architecture is influenced by the social, economic and cultural environments or different. Works of architecture that made the object of observation in this study is housing because the residence is the object of a common architecture and known and easiest to read. For information submitted regarding whether "he" is and what "she" can do to make the observer to know the true meaning. To read the sign as an architectural understanding can be done through a method of approach, namely through the semiotic method. Where through this approach the observer can see the way a good sign for prepared and read as a language.Outcomes of this research is a scientific article published in the Journal ISSN Local. The results of this study are expected to guide architectural education, especially in college in making policy curriculum and syllabus of lecture material in order to obtain a proper curriculum policy and weighted for the basic education system architectures as well as material enrichment courses Introduction to Architecture. Thus, students who undergo architectural education can understand the architecture with up and easy to apply in the field.

Keywords: architecture, curriculum, student of architecture, mental image, houses,, semiotic 


\section{Pendahuluan}

Di pendididikan tinggi, arsitektur merupakan salah satu disiplin ilmu yang dipelajari secara khusus seperti disiplin ilmu lainnya. Secara umum, pemahaman dan penafsiran arsitektur dapat dilakukan oleh semua orang dan yang paling mudah dilakukan adalah dengan melihat bentuk suatu obyek. Pemahaman tentang arsitektur dipengaruhi oleh ruang lingkup arsitektur, secara fisik menentukan pendapat tentang arsitektur. Ini dipengaruhi oleh kerangka sosial, ekonomi dan budaya serta masyarakat setempat dimana obyek berada.

Pemahaman dan pengenalan tanda arsitektur merupakan salah satu ilmu dasar dalam pendidikan arsitektur yang lebih dikenal dengan nama semiotika. Pengenalan tanda dari suatu bangunan sebagai komunikasi didalam arsitektur paling mudah dilakukan terhadap fasade bangunan. Karena fasade bangunan merupakan bagian yang sifatnya berinteraksi langsung secara visual kepada manusia sebagai pengamat dan juga bersifat paling komunikatif.

Penandaan dapat dilakukan dengan melihat dan membaca elemen yang mudah dikenal pada bagian obyek tersebut sehingga obyek tersebut mudah untuk dipetakan dan diingat.

"Penandaan didalam arsitektur dilakukan dengan membaca elemen-elemen arsitektural, dan elemen arsitektural secara fisikal pada bangunan dapat diberi nama, seperti kolom, lantai dan arch. Dengan demikian, objek dapat diingat oleh pengguna untuk membentuk atau menciptakan karakter tempat". (Jonathan A. Hale, terjemahan, 2002 :13)

Obyek penelitian ini adalah bangunan rumah tinggal sebagai obyek arsitektur yang paling mudah dan umum dikenal oleh masyarakat awam. Rumah sebagai tempat bernaung merupakan hasil proses perancangan yang dari dulu hingga kini terus mengalami perkembangan didalam memenuhi kebutuhan akan ruang untuk beraktifitas. Sebagai salah satu karya arsitektur, rumah memiliki wujud yang merupakan hasil konfigurasi tertentu. Permukaan bentuk memiliki karakter yang terbentuk dari elemen pembentuknya. Karakter ini memberikan bobot visual terhadap rumah dan juga yang akan membedakan rumah dengan lingkungannya.

Masyarakat umum yang dilibatkan pada penelitian ini adalah mahasiswa baru arsitektur ITM angkatan 2015, karena mereka belum menjalani pendidikan arsitektur secara khusus untuk mendapat pengetahuan tentang arsitektur yang sebenarnya.

Adapun tujuan dari penelitian ini adalah:

1. Menginventarisasi elemen elemen bangunan rumah tinggal yang memiliki potensi untuk dapat dijadikan penanda sebagai identitas.

2. mendapatkan metide pemenfaatan elemenelemen bangunan rumah tinggal sebagai identitas dalam proses perencanaan bangunan.

3. Untuk melihat tingkat pemahaman mahasiswa sebagai masyarakat awam terhadap elemen rumah tinggal yang dikenal sebagai penanda untuk menginterpretasikan arsitektur sebelum menjalani pendidikan arsitektur sehingga diperoleh faktor-faktor perangsang ketekunan menjalani pendidikan arsitektur melalui peta mental.

Dari penelaahan yang dilakukan pada penelitian ini, diharapkan dapat menjadi informasi yang dapat dijadikan sebagai pedoman didalam menyusun kurikulum dan silabus materi perkuliahan pada pendidikan arsitektur khususnya di pendidikan tinggi sehingga akan diperoleh suatu kebijakan kurikulum yang tepat bagi sistem pendidikan arsitektur sesuai kebutuhan dan metode pembelajaran yang tepat bagi mahasiswa sesuai dengan tingkat kemampuan dan pemahaman mereka terhadap arsitektur.

Dari hasil pemaparan diatas, maka penelitian ini dapat mengambil rumusan masalah sebagai berikut:dengan membaca elemen bangunan rumah tinggal yang dijadikan sebagai penanda dapat membentuk persepsi atau image mahasiswa tentang pengertian arsitektur sehingga dapat membantu mereka dalam mempelajari arsitektur di pendidikan tinggi.

\section{Kajian Teori}

\subsection{Pengertian Image}

Image berasal dari bahasa Inggris yang berarti gambaran; bayangan. Image arsitektur terbentuk karena adanya pengamatan langsung terhadap suatu obyek arsitektur melalui suatu proses penghayatan dan tersimpan didalam ingatan. Beberapa pengertian tentang image, antara lain menurut:

a. Kevin Lynch; dalam The Image of The City

Image merupakan suatu citra yang tersimpan dalan ingatan yang kemudian 


\section{Kajian Mental Image Mahasiswa Arsitektur Terhadap Arsitektur dengan Metode Pendekatan Semiotik}

akan mempengaruhi perilaku. Dimana citra ini terbentuk dari obyek-obyek arsitektur yang merupakan bahan informasi untuk dipersepsikan, diingat dan digunakan.

Suatu individu mengalami reaksi terhadap lingkungan fisik bangunan dan perkotaan yang mereka lihat dan reaksi tersebut menjadi pengalaman berupa image terhadap bangunan dan lingkungan yang tersimpan didalam ingatan. Obyek-obyek arsitektur merupakan bahan-bahan informasi yang siap untuk dipersepsikan, diingat dan digunakan.

Kevin Lynch, seorang tokoh peneliti perkotaan melakukan penelitian berdasarkan pemetaan kognitif sejumlah penduduk dari perkotaan tersebut. Pada penelitiannya tersebut, Lynch meminta kepada para penduduk untuk menjelaskan kepadanya suatu gambaran mental terhadap kota mereka. Kevin Lynch telah menelusuri pengamat dengan hasil bahwa image yang terjadi karena adanya penangkapan atribut-atribut kota yang langsung "dibaca" oleh pengamat. Berbagai jawaban yang diberikan oleh pengamat ratarata agak sama dan sering jauh berbeda dengan realitas di dalam kawasan. Misalnya, sketsasketsa yang dibuat orang dengan tim peneliti sering jauh berbeda dengan peta kota yang sebenarnya. Ia mengamati, bahwa masalah itu terutama tidak disebabkan oleh ketidakbiasaan orang untuk menggambar sketsa, namun karena adanya kesulitan untuk mengingat keadaan tempatnya.

Lynch mengamati, bahwa di beberapa kota dan berbagai kawasan lainnya, masalah tersebut lebih sedikit dialami orang. Di dalam penelitian ini telah diteliti dari mana perbedaan itu berasal dan mengapa di berbagai kota orang memiliki gambaran mental yang lebih kuat terhadap kawasannya daripada tempat yang lainnya. Berdasarkan analisis tersebut, Lynch (1960:8 dalam 2005:17) menemukan, bahwa image suatu kawasan yang tergambar dari peta mental seseorang berkaitan dengan tiga komponen, yaitu:

1. Identitas, artinya orang dapat memahami gambaran mental suatu obyek (identifikasi obyek-obyek, perbedaan antara obyek, perihal yang dapat diketahui) atau dengan pengertian lain merupakan obyek atau elemen yang memiliki karakter dan kekhasan sebagai jatidiri yang dapat membedakannya dengan obyek lainnya
2. Struktur, artinya orang dapat melihat pola hubungan antar obyek, hubungan subyekobyek atau yang mencakup pola hubungan antara elemen satu dengan yang lainnya pada kawasan yang dapat dipahami dan dikenali oleh pengamat.

3. Makna, merupakan pemahaman arti oleh pengamat terhadap dua komponen tersebut diatas.

Menurut Lynch, bahwa pembangunan kota hendaknya berorientasi kepada penataan yang mudah "dibaca" (higly legible). Dimana penelitiannya mengarah kepada pengidentifikasian elemen-elemen struktur fisik yang membuat kota memberikan kesan. Kesimpulannya, terdapat lima kategori elemen yang digunakan orang untuk menyusun kesadaran atas image kawasan dan merupakan unsur dasar sebuah image kawasan secara keseluruhan, yaitu paths, edges, district, nodes, dan landmarks.

Semua elemen ini berfungsi bersama dalam suatu kawasan yang sama. Dengan memiliki kelima elemen tersebut beserta campurannya, tidak berarti bahwa sebuah kota langsung mempunyai image yang baik. Karena itu, perlu diperhatikan kualitas formulasi kelima elemen tersebut dengan yang lain.

Metode Kevin Lynch ini akan digunakan sebagai metode pendekatan didalam mengamati elemen-elemen pembentuk fasade rumah tinggal yang mengalami perubahan dan dijadikan penanda setelah menjalani pendidikan arsitektur.

\section{b. David Stea; Pemetaan Kognitif}

Image yaitu satu upaya pemahaman terhadap suatu tempat atau obyek melalui suatu peta mental. Istilah peta mental disini adalah suatu proses yang memungkinkan untuk mengumpulkan, mengorganisasikan, menyimpan dalam ingatan, memanggil dan menguraikan kembali informasi tentang lokasi maupun tanda-tanda tentang suatu obyek melalui pengamatan langsung, dari seseorang yang pernah mendengar langsung maupun dari informasi yang dibayangkan. Image dapat menjadi sesuatu yang terbaik sebagai tanda penunjuk.

Dengan demikian dapat dilihat, bahwa image secara umum sering dihubungkan dengan citra, pandangan, pemahaman, pendapat, perilaku dan persepsi. 


\subsection{Seimotika Dalam Arsitektur}

Semiotik dalam arsitektur mulai disinggung pada tahun 1937 oleh Mukarovsky, yang mempertanyakan fungsi dalam arsitektur estetiknya. Namun semiotik secara eksplisit masuk dalam bahasan arsitektur menurut Charles Jencks dimulai di Italia pada akhir tahun lima puluhan abad ini pada saat timbul krisis makna di Eropa.

Semiotika merupakan ilmu yang mempelajari tanda-tanda (JP, Bonta, 1979:26) dan istilah semiotika sering diidentikkan dengan suatu gaya bahasa untuk mempermudah komunikasi didalam arsitektur. Semiotika lebih condong kepada pendekatan kualitatif. Dan semiotika dapat diterapkan pada arsitektur karena adanya anggapan bahwa arsitektur merupakan bahasa yang memiliki kompleksitas tanda yang disusun menurut aturan tertentu dengan analisa makna sering dipusatkan pada makna eksplisit yang bersifat sebagai makna tetap.

Semiotika sebagai kajian sistem tandatanda dipakai dalam uraian arsitektur semula untuk menanggapi krisis makna yang dirasakan oleh beberapa pakar arsitektur Eropa. Para arsitek semiotik membedakan dirinya dengan yang lainnya melalui pemakaian tanda. Penandaan dari elemenelemen juga dapat mempermudah proses visual pengamat terhadap suatu obyek arsitektur, begitu juga didalam proses untuk mengingatnya kembali. Penglihatan dan ingatan ini akan berkembang menjadi sebuah image tersendiri dari tiap-tiap individu terhadap apa yang diamatinya.

Charles Jencks memaparkan bahwa tanda arsitektur memiliki bidang ekspresi atau penanda dan bidang isi atau petanda. Pemaparannya ini berdasarkan pada model semiotika yang dikemukakan oleh Saussure, Hjemslev dan Umberto Eco. Dimana bentuk, ruang, permukaan dan volume yang memiliki suprasegmental seperti warna, tekstur, kepadatan dan lainnya dapat berperan sebagai penanda sedangkan gagasan-gagasan yang tidak terlalu rumit, seperti ikon, makna tertentu, makna estetis, ide arsitektur, konsep ruang, keyakinan/kepercayaan masyarakat, fungsi, aktifitas dan lainnya dapat dianggap sebagai petanda (Gunawan Tjahjono, dalam prosiding Seminar Semiotik, 1992:6)

$>$ Substance of content (signified) adalah segenap nilai-nilai, ide-ide dan filosofi yang melatar belakangi konsep perwujudan hasil karya arsitektur.

$>$ Form of content (signified) adalah segenap himpunan konsep-konsep perencanaan dan perancangan arsitektur yang akan ditransformasikan ke dalam wujud/karya arsitektur.

$>$ Form of expression (signifier) adalah form of content yang diekspresikan ke dalam bentuk fisik bangunan baik secara utuh maupun komponennya.

> Substance of expression adalah makna yang muncul dibalik form of expression wujud arsitektur.

Pada penelitian ini, teori yang digunakan didalam membaca elemen fisik fasade bangunan rumah tinggal yang dijadikan sebagai obyek adalah teori yang digunakan oleh Charles Jencks. Dimana bentuk, ruang, permukaan dan volume yang memiliki suprasegmental dapat berperan sebagai penanda sedangkan gagasan, fungsi dan aktifitas berperan sebagai petanda.

Hal ini dilakukan karena pembacaan terhadap elemen pembentuk dan campurannya hanya pada bagian fasade bangunan saja yang dapat dikatakan sebagai bidang ekspresi (penanda).

\section{Metode Penelitian}

\subsection{Lokasi dan Waktu Penelitian}

Pembangunan rumah sebagai sarana tempat tinggal, mulai dari tipe yang kecil hingga besar, rumah tipe sederhana hingga mewah saat ini sangat dibutuhkan oleh masyarakat khususnya masyarakat kota Medan sebagai salah satu kota terbesar di Indonesia. Sejalan dengan itu, banyak perusahaan yang bergerak dibidang pengembangan perumahan (developer) saling berlomba membangun komplek-komplek perumahan mulai pada lahan di tengah kota hingga di pinggiran kota. Hal ini bertujuan untuk memenuhi kebutuhan penduduk akan perumahan.

Pembangunan perumahan di kota Medan sangat pesat terjadi antara tahun 19901996 sebelum krisis ekonomi melanda Indonesia. Setelah itu, pembangunan perumahan dapat dikatakan hampir tidak ada terjadi. Namun, sejak awal tahun 2003 hingga sekarang, pembangunan perumahan mulai kembali bangkit secara perlahan-lahan.

Pada penelitian ini obyek pengamatan dilakukan pada rumah tinggal yang berada di 


\section{Kajian Mental Image Mahasiswa Arsitektur Terhadap Arsitektur dengan Metode Pendekatan Semiotik}

kawasan komplek Perumahan Taman Setiabudi Indah, Kelurahan Tanjung Rejo, Kecamatan Medan Sunggal, Kota Medan dengan mengambil salah satu bangunan rumah tinggal sebagai obyek pengamatan. Dipilihnya lokasi ini sebagai tempat penelitian karena komplek perumahan ini dianggap memenuhi standar perumahan yang baik

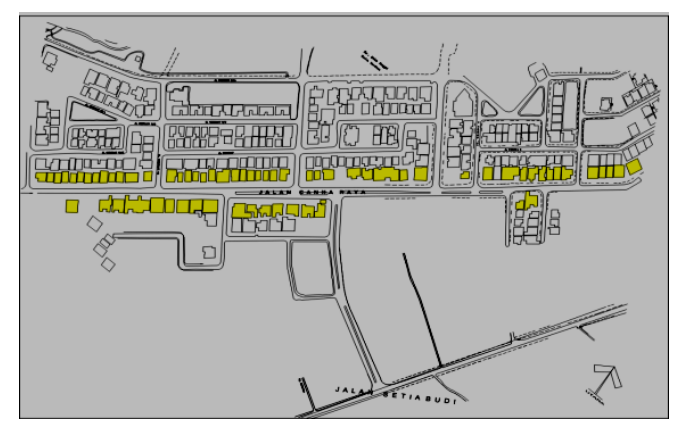

Gambar 1. Peta lokasi penelitian Perumahan Taman Setiabudi Indah

Perumahan Taman Setiabudi Indah merupakan kawasan perumahan yang termasuk perumahan elit pertama di kota Medan. Perumahan Setiabudi Indah terletak di Kelurahan Tanjung Rejo Kecamatan Medan Sunggal Kota Medan. Saat ini kawasan Taman Setiabudi Indah terdiri atas tiga sub bagian, yaitu Kawasan Taman Setiabudi Indah I, Taman Setiabudi Indah II dan Bukit Hijau Regency.

Pembangunan perumahan ini dilaksanakan secara bertahap, dimana tahap pertama dilaksanakan pada tahun 1984 dengan luas lahan perumahan seluas 46 hektar kemudian tahun 1985 bertambah menjadi 60 hektar. Pada tahun 1987, perumahan ini mencapai luas 160 hektar dan disebut sebagai Taman Setiabudi I dan Kawasan Eksklusif Bukit Hijau Regency (BHR). Tahap selanjutnya adalah pembangunan Taman Setiabudi Indah II seluas 40 hektar, sehingga jumlah luas keseluruhan untuk kawasan Taman Setiabudi Indah ini mencapai 200 hektar dengan jumlah rumah terbangun dan dihuni sekitar 3000 unit dan jumlah penghuni sekitar 15.000 jiwa. Kawasan ini merupakan kawasan real estate dengan sarana dan prasarana yang cukup lengkap sehingga dapat dikatakan sebagai kota satelit dalam skala kecil dengan fasilitas layaknya suatu kota mandiri.
Perkembangan

pembangunan perumahan di Taman Setiabudi Indah dengan tahapan-tahapan sesuai dengan arah perkembangan dan pembebasan lahan dan pematangan tanah. Adapun tipe rumah yang terbangun demikian bervariasi, berupa tipe kecil T-36 sampai T-70. tipe menengah T-70 sampai T-100 dan tipe besar T-100 sampai T1000. Tabel berikut menunjukkan tahapan pembangunan rumah di Taman Setiabudi Indah.

Tabel 1. Tahapan Pembangunan Rumah Tinggal di Taman Setiabudi Indah (unit)

\begin{tabular}{cccc}
\hline $\begin{array}{c}\text { TIPE } \\
\text { RUMAH }\end{array}$ & THP I & THP II & THP III \\
\hline $36-40$ & 136 & - & - \\
\hline $45-49$ & 48 & - & - \\
\hline $50-59$ & 222 & 86 & - \\
\hline $60-69$ & 124 & 126 & - \\
\hline $70-79$ & 664 & 190 & - \\
\hline $80-99$ & 185 & 16 & - \\
\hline $100-149$ & 446 & 60 & - \\
\hline $150-179$ & 145 & 26 & - \\
\hline $180-199$ & 11 & 27 & - \\
\hline $200-350$ & 58 & 44 & 43 \\
\hline $400-600$ & 8 & - & 3 \\
\hline $800-1000$ & - & - & 1 \\
\hline JUMLAH & 2047 & 575 & $\mathbf{4 7}$ \\
\hline
\end{tabular}

Sumber : Divisi Pengelola Perumahan Taman Setiabudi Indah (2009)

Bila melihat kepada rencana perkembangan Perumahan Taman Setiabudi Indah, dapat dilihat bahwa perencanaan kawasan ini sudah memperhitungkan segala kemungkinan yang timbul akibat adanya perumahan ini terutama terhadap lingkungan sekitarnya. Perumahan Taman Setiabudi Indah dapat dikatakan sudah memperhitungkan gejala perkembangan kegiatan disekitar perumahan terutama pada gejala social masyarakat antara lain dengan memperhatikan perkembangan daerah sekitar sehingga tidak terjadi kesenjangan sosial antara penghuni yang ada di dalam kawasan maupun penghuni yang berada di sekitar kawasan. 
Hal tersebut ditandai dengan adanya keterkaitan antara fasilitas perumahan dan pemukiman dengan fasilitas lingkungan dimana masyarakat sekitar dibebaskan untuk dapat menikmati secara bebas fasilitas umum yang menyangkut kepentingan masyarakat banyak. Selain itu, pihak pengelola juga memperhatikan interaksi hubungan sirkulasi antara kawasan dengan daerah sekitar dimana terdapat koneksitas sirkulasi antara perumahan dengan lingkungan.

Dari tingkat kepadatan, komplek perumahan ini dapat dikatakan cukup padat pada saat ini, karena orang lebih memutuskan untuk bertempat tinggal di perumahan ini. Hal tersebut disebabkan karena Perumahan Taman Setiabudi Indah dilengkapi dengan fasilitas yang cukup memadai, seperti open space yang luas, pusat perbelanjaan, poliklinik, golf drive, fasilitas ibadah dan lain sebagainya.

Adapun bangunan rumah tinggal yang dijadikan sebagai objek pengamatan adalah sebagai berikut:

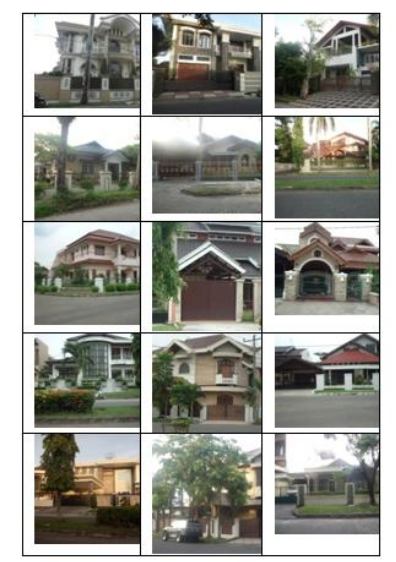

Gambar 2. Objek pengamatan

\section{Hasil dan Pembahasan}

4.1 Image Arsitektur Sebelum Berpendidikan

Image sebelum berpendidikan yang dimaksud disini adalah pendapat atau komentar mahasiswa arsitektur sebelum mendapat pendidikan formal dalam bidang ilmu arsitektur, dimana mereka dianggap sama dengan masyarakat awam pada umumnya. Pada penelitian ini,sampel yang digunakan adalah mahasiswa program studi arsitektur angkatan 2015 yang baru memasuki pendidikan tinggi di Institut Teknologi Medan.

Image yang diberikan pada fisik fasade bangunan adalah terhadap elemen-elemen pembentuk fasade rumah tinggal dan campurannya yang muncul dari hasil pengamatan terhadap obyek kasus. Seperti metode pendekatan yang dilakukan oleh Kevin Lynch, maka pengamatan dilakukan secara langsung dengan pengidentifikasian terhadap elemen fisik pada fasade suatu rumah tinggal yang dapat dijadikan penanda. Dari hasil pengamatan tersebut, maka elemen yang muncul adalah bentuk yang mencakup pada bentuk atap dan bangunan, atap, dinding, jendela dan pintu dengan elemen campurannya, seperti warna, gaya bangunan, ornamen dan bahan yang digunakan. Pada pengamatan ini, pengamat memberikan penilaian lebih dari satu elemen.

Dari hasil kuesioner, dapat dilihat bahwa elemen yang sering muncul dari hasil pengamatan yang dilakukan adalah elemen campuran berupa atap, bentuk dan pintu yang digunakan dengan komentar yang masih bersifat umum dan tidak spesifik. Hal ini disebabkan karena belum adanya pengetahuan mereka tentang arsitektur yang diperoleh secara khusus melalui pendidikan.

Adapun elemen yang dianggap menarik dan dapat dikategorikan sebagai penanda dari rumah tinggal dengan ketentuan apabila dikomentari lebih dari setengah dari jumlah pengamat $(\geq 1 / 2 \mathrm{n})$. Elemen-elemen tersebut adalah:

1. Bentuk

Elemen ini secara umum juga merupakan hal yang paling menarik bagi pengamat untuk dikomentari sebagai penanda dari rumah tinggal. Walaupun bentuk ini belum tentu disukai oleh pengamat lainnya sebagai suatu elemen yang menarik. Bentuk disini merupakan penampilan estetika bangunan secara fisik.

\section{Atap dan bahan}

Atap merupakan elemen juga banyak dikomentari dari rumah tinggal. Elemen ini merupakan suatu elemen yang dianggap menarik dan dapat dijadikan sebagai penanda untuk mengenali rumah tinggal. Atap yang dikomentari disini semata-mata merupakan bentuk visual Yang ditampilkannya bukan dari kekhasan dari atap tersebut. Sedangkan bahan yang digunakan secara umum merupakan bahan yang kebanyakan digunakan pada bangunan lainnya dan umum dijumpai. 


\section{Kajian Mental Image Mahasiswa Arsitektur Terhadap Arsitektur dengan Metode Pendekatan Semiotik}

Pintu dan jendela

Kedua elemen ini merupakan elemen fisik yang menarik untuk dikomentari sebagai penanda rumah tinggal disamping ketiga elemen diatas. Bentuk pintu dan jendela dikomentari dari bentuk, hiasan dan bahan yang digunakan.

\section{KESIMPULAN}

Dari pembahasan diatas, dapat diambil kesimpulan bahwa:

1. Pemahaman seseorang terhadap arsitektur berbeda dipengaruhi oleh latar belakang keluarga, pendidikan, sosial dan budaya orang tersebut.

2. Seseorang dapat memahami "apa itu Arsitektur" dapat dilakukan dengan membaca "tanda" yang terdapat pada objek yang dilihatnya.

3. Pembacaan tanda dapat dilakukan dengan pendekatan semiotika yaitu suatu ilmu yang mempelajari tentang tanda dan petanda yang diperoleh melalui pendidikan arsitektur.

\section{SARAN}

1. Untuk mendapatkan hasil yang lebih maksimal dalam tingkat pemahaman mahasiswa terhadap arsitektur pada penelitian ini sebaiknya jumlah responden lebih banyak lagi (minimal 100 responden) untuk lebih memaksimalkan tingkat rigiditas data.

2. Perlu adanya penyesuaian materi dasar pendidikan berdasarkan latar belakang mahasiswa yang baru memasuki pendidikan arsitektur agar mahasiswa dapat mengikuti perkuliahan arsitektur secara maksimal.

3. Perlu adanya peninjauan ulang kurikulum pada pendidikan arsitektur secara berkala guna penyesuaian terhadap tingkat kebutuhan pengetahuan terhadap arsitektur yang sesuai dengan perkembangan ilmu dan teknologi.

\section{DAFTAR PUSTAKA}

Amos, Rapoport:

House, Form And Culture, Prentice-Hall International, Inc., London, 1969

Aryanto, Achmad:
Elemen Pembentuk Citra Kawasan Perumahan, Tesis, Program Magister Teknik Arsitektur, Universitas Sumatera Utara, 2004

Bechtel B. Robert, et.al:

Methods In Environmental And Behavioral Research, Van Nostrand, Reinhold Company, New York, 1987

Bonta, JP:

Notes For A Theory Of Meaning In Design, dalam Sign, Symbol And Architecture, John Willey \& Sons, 1980

Broadbent,Geoffrey, et.al:

Sign, symbol And Architecture, John Willey \& Sons, Inc., 1980

Groat, Linda, et.al:

Architectural Research Methods, John Willey \& Sons, Inc., 2002

Halle, A. Jonathan:

Building Ideas, An Introduction To Architecture Theory, terjemahan oleh Ir. M. Nawawiy Loebis, M.Phill, PhD., handout Mata Kuliah Filsafat Arsitektur.

Jencks, Charles:

The Arsitectural Sign, dalam Sign, Symbol And Architecture, John Willey \& Sons, 1980

Prosiding:

Seleksi Kumpulan Makalah, Seminar Semiotik, Jakarta, 21-22 Desember 1992

Laurens, Marcella Joyce: Arsitektur Dan Perilaku Manusia, PT. Grasindo, Jakarta, 2004

Lynch, Kevin: The Image Of The City, The MIT Press, London, 1960

Moleong, Lexy: Metodologi Penelitian Kualitatif, PT. Remaja Rosdakarya, Bandung, 2000 